\title{
KAJIAN FUEL ECONOMY MENGGUNAKAN BAHAN BAKAR GAS DAN BERBAGAI BENSIN YANG TERSEDIA DI INDONESIA PADA KENDARAAN SEDAN DAN MPV
}

\section{STUDY ON FUEL ECONOMY OF SEDAN AND MPV VEHICLES FUELED WITH GAS FUEL AND VARIOUS MARKET FUEL IN INDONESIA}

\author{
Budi Rochmanto ${ }^{a}$, Hari Setiapraja ${ }^{a}$, Rizqon Fajar ${ }^{b}$ \\ a Balai Teknologi Termodinamika, Motor dan Propulsi, Deputi Bidang TIRBR, BPPT. \\ b Pusat Teknologi Sistem dan Prasarana Transportasi, Deputi Bidang TIRBR, BPPT. \\ e-mail : budi.rochmanto@bppt.go.id, hari.setiapraja@bppt.go.id, rizqon.fajar@bppt.go.id
}

\begin{abstract}
Abstrak
Menipisnya persediaan minyak bumi sebagai salah satu sumber energi telah membuat pemerintah Indonesia melakukan efisiensi energi dimana salah satunya adalah menjadikan bahan bakar gas sebagai bahan bakar alternative. Penelitian bahan bakar gas untuk kendaraan telah dilakukan diberbagai negara termasuk Indonesia. Pada paper ini telah dilakukan kajian teknis mengenai pengaruh pemakaian berbagai bahan bakar gasoline yang tersedia dipasar Indonesia dan bahan bakar gas CNG pada kendaraan sedan dan MPV. Kajian ini bertujuan untuk mengetahui pengaruh penggunaan bahan bakar minyak khususnya bensin dan gas CNG pada emisi gas buang, konsumsi bahan bakar, dan biaya operasional kendaraan dengan menggunakan bahan bakar bensin dan CNG. Pengujian dilakukan dengan menggunakan 2 jenis kendaraan yaitu sedan dan MPV yang memiliki kapasitas silinder 1500 cc memakai 4 bahan bakar jenis bensin dengan nilai oktan yang berbeda-beda dan 1 bahan bakar gas (CNG). Metode uji emisi gas buang menggunakan standar Euro 2 sedangkan pengujian konsumsi bahan bakar menggunakan standar UN ECE R101. Hasil pengujian menunjukkan bahwa emisi gas buang untuk $\mathrm{CO}$ dan $\mathrm{CO}_{2}$ bahan bakar gas lebih rendah dari pada untuk bahan bakar bensin, tapi hal ini sebaliknya untuk emisi NOx dan THC. Tetapi untuk konsumsi bahan bakar gas yang disetarakan dengan LSP (liter setara premium) hasilnya lebih boros dibandingkan dengan bahan bakar bensin untuk satuan liter per $\mathrm{km}$. Tetapi untuk biaya pemakaian bahan bakar per $\mathrm{km}$, penggunaan bahan bakar gas CNG mempunyai nilai ekonomis yang lebih baik dibanding bahan bakar bensin dikarenakan harga bahan bakar gas CNG yang masih lebih rendah dibanding jenis bensin.
\end{abstract}

Kata kunci : CNG, Bensin, Konsumsi bahan bakar, Emisi gas buang, Fuel economy

\begin{abstract}
Scarcity of fossil fuels as one of energy resources has made energy efficiency by Indonesian Government which one of the program is making gas as an alternative fuel. Research on utilization of gas fuel on spark ignition engine has been done massively at all over the world including Indonesia. In this paper, study has been done to investigate effect of market fuels in Indonesia and CNG at sedan and MPV vehicles. The purpose is to evaluate an effect of gas fuel and market fuel on emissions, fuel economy and operational cost of vehicle. An experiment was conducted on sedan and MPV with has cylinder capacity of 1500 cc using
\end{abstract}


4 kinds of market fuel in Indonesia and CNG. Test method for emissions testing and fuel economy were Euro2 standard and R101 respectively. The results showed that exhaust emission of $\mathrm{CO}$ and $\mathrm{CO}_{2}$ from gas fuel was lower than gasoline while for NOx and THC of gas fuel was higher than gasoline. Moreover, fuel consumption in which for CNG converted into liter gasoline equivalent(LSP) showed the higher result for CNG compared to that of gasoline. However operasional cost for CNG is much lower than gasoline due to cheaper price of CNG.

\section{Keyword : CNG, Gasoline, Fuel consumption, Exhaust gas emission,} Fuel economy

Diterima (received ) : 17 Juli 2018, Direvisi (revised) : 16 Agustus 2018

Disetujui (accepted) : 29 Agustus 2018

\section{PENDAHULUAN}

\section{Latar Belakang}

Pertumbuhan jumlah kendaraan dan perkembangan industri telah mendorong konsumsi bahan bakar minyak (BBM) di Indonesia. Pertumbuhan konsumsi yang tidak dapat diimbangi dengan kapasitas produksi yang dihasilkan Indonesia telah membuat Indonesia menjadi negara pengimpor bahan bakar fosil. Konsumsi BBM di Indonesia pada tahun 2015 mencapai 51 juta kilo liter, tahun 2017 mencapai 75 juta kilo liter, dan diperkirakan pada Tahun 2025 akan mencapai angka 127 juta kilo liter ${ }^{1}$. Konsumsi tersebut didominasi oleh sektor transportasi dengan pemakaian bahan bakar bersubsidi yang mencapai angka diatas 90 persen. Dalam hal pemenuhan konsumsi yang besar tersebut, Indonesia sudah menjadi Negara importir karena produksi minyak bumi tidak dapat mengimbangi kebutuhannya.

Sebagai negara pengimpor BBM, Indonesia sudah meningkatkan eksplorasi cadangan minyak bumi untuk kebutuhan di dalam negeri. Tetapi dengan peningkatan kebutuhan bahan bakar yang tinggi maka diperlukan diversifikasi penggunaan bahan bakar minyak. Hal ini dinyatakan oleh Peraturan Pemerintah No.79 Tahun 2014 tentang kebijakan energi nasional yang membahas target bauran energi sampai dengan 2050.

Dampak pembauran energi yang tercantum dalam kebijakan pemerintah tersebut dapat berakibat pada 3 komponen utama. Pertama, ketahanan energi. Sebagai negara yang mendominasi kebutuhan energinya dari impor maka energy security menjadi kendala untuk menjadi negara yang berdaulat. Dengan diversifikasi energi diharapkan adanya pengurangan jumlah impor, mengurangi ketergantungan terhadap bahan bakar minyak dan ketahanan terhadap cadangan energi nasional dapat dijaga. Faktor kedua adalah dampak ekonomi. Kajian teknis sudah melaporkan bahwa berbagai bahan bakar alternatif pengganti minyak dapat menghasilkan biaya operasional yang murah dan juga dapat meningkatkan investasi dalam negeri melalui pembangunan infrastrukturnya. Untuk Indonesia, pengurangan pemakaian bahan bakar minyak bersubsidi juga akan secara signifikan menghemat devisa negara. Dan faktor terakhir adalah dampak lingkungan. Lingkungan sudah menjadi isu internasional dalam pengembangan energi saat ini. Peraturan Presiden No. 61 Tahun 2011 telah secara jelas menyebutkan mengenai rencana aksi nasional penurunan emisi gas rumah kaca. Dalam bidang transportasi, berbagai bahan bakar alternatif merupakan sumber menjanjikan untuk mengurangi emisi gas rumah kaca sebesar $25 \%$.

Dalam kajian ini berbagai bahan bakar bensin yang sudah beredar di Indonesia dan bahan bakar gas jenis CNG akan dikaji dari segi emisi, konsumsi bahan bakar dan fuel economy. Hal ini ditujukan untuk memberikan informasi terkait perbandingan nilai ekonomi dari setiap bahan bakar untuk memberikan rekomendasi terkait pemakaian bahan bakar yang sesui dengan potensi sumber daya dan teknologi kendaraan yang berada di Indonesia.

\section{Tujuan}

Kajian ini bertujuan untuk :

a. Mengetahui perbandingan emisi dan konsumsi bahan bakar pada berbagai bahan bakar jenis bensin yang beredar di indonesia dan bahan bakar gas jenis CNG.

b. Mengetahui tingkat ekonomis pemakaian bahan bakar yaitu perbandingan biaya pemakaian bahan bakar per km untuk bahan bakar jenis 
bensin yang beredar di indonesia dan bahan bakar gas jenis CNG.

c. Mengetahui perbedaan karakteristik emisi dan konsumsi bahan bakar untuk bahan bakar minyak jenis bensin dan bahan bakar gas jenis CNG.

\section{TINJAUAN PUSTAKA}

Peraturan Menteri Negara LH No. 04 Tahun 2009 mengatur tentang regulasi emisi gas buang kendaran bermotor dengan baku mutu emisi $\mathrm{CO}, \mathrm{HC}$, NOx untuk kendaraan bensin dan ditambahkan dengan PM untuk kendaraan diesel. Metodologi dan ambang batasnya mengacu kepada standar UNECE R83-02 atau EURO II. Hasil kajian Kementerian Lingkungan Hidup menunjukkan bahwa pemberlakuan regulasi Euro 2 dapat secara signifikan menurunkan polusi udara jika dibandingkan dengan skenario tanpa penerapan Euro 22,3). Jadi pemberlakuan ambang batas yang lebih ketat sangat efektif untuk mengontrol polusi udara dari kendaraan bermotor. Dalam mengontrol emisi kendaraan bermotor, strategi yang dapat dilakukan adalah merubah teknologi kendaraan dan menggunakan bahan bakar yang ramah lingkungan. Dalam teknologi kendaraan, hal yang telah dilakukan adalah optimasi dari segi pembakaran baik dari sistem kontrol maupun sistem mekaniknya juga pemakaian sistem exhaust after treatment yang dapat menekan emisi sampai pada titik yang sangat rendah. Sedangkan untuk pemakaian bahan bakar ramah lingkungan untuk kendaraan bensin, maka bioetanol, bahan bakar gas baik Liquified Petroleum Gas (LPG) maupun Compress Natural Gas (CNG), Gas to Liquid (GTL) dan lain-lain merupakan alternatif yang dapat dipilih untuk mendapatkan gas buang yang rendah sehingga pemakaiannya didorong oleh PP No. 79 Tahun 2014 terkait bauran energi nasional maupun PP No. 13 Tahun 2013 tentang keringanan pajak untuk teknologi kendaraan dengan bahan bakar ramah lingkungan dan hemat energi.

Kajian terkait bahan bakar gas telah banyak dilakukan dimana secara umum menunjukkan hasil daya maksimum yang lebih rendah, emisi NOx dan $\mathrm{HC}$ yang lebih tinggi dan juga pemakaian konsumsi bahan bakar yang lebih boros ${ }^{4,5,6}$. Tetapi kajian tersebut juga menunjukkan bahwa potensi untuk mengatasi permasalahan tersebut dapat dilakukan dengan optimasi parameter engine pada converter kit bahan bakar gas ${ }^{6}$, engine tune up ${ }^{7)}$ maupun dengan menggunakan catalytic converter untuk mengurangi emisi $\mathrm{HC}$ dan $\mathrm{NO}^{5}$ ). Selain hal tersebut teknologi pembakaran dengan dual fuel gas dengan hydrogen ${ }^{8)}$ maupun gas dengan Dimetil Ether (DME) ${ }^{9}$ ) dapat menjadi salah satu solusi dalam pemakaian bahan bakar gas yang lebih ramah lingkungan dan efisien.

\section{METODE PENELITIAN}

Secara umum kajian fuel economy dilakukan dengan tahapan sebagai berikut:

a. Pengujian kendaraan dengan menjalankan kendaraan di atas chassis dynamometer, dan mengambil gas buang.

b. Analisis kandungan gas buang kendaraan, untuk mendapatkan parameter emisi.

c. Perhitungan konsumsi bahan bakar dari parameter emisi dengan metode carbon balance.

d. Perhitungan biaya pemakaian bahan bakar per kilometer pada kendaraan.

Adapun uraian metode dan langkah kegiatan yang dilakukan dalam kajian ini adalah :

\section{Standar Pengujian}

Pengujian konsumsi bahan bakar dilakukan dengan standar global untuk pengujian kendaraan yang dikeluarkan oleh United Nations Economic Commission for Europe, yakni UN ECE R10110).

a. Siklus kecepatan

Siklus kecepatan pada standar uji UN ECE R101 terdiri atas dua siklus, yakni siklus perkotaan (urban) dengan tiga pengulangan dan siklus luar kota (extra urban) ${ }^{10)}$. Siklus kecepatan kendaraan dalam pengujian ini ditunjukkan Gambar 1.

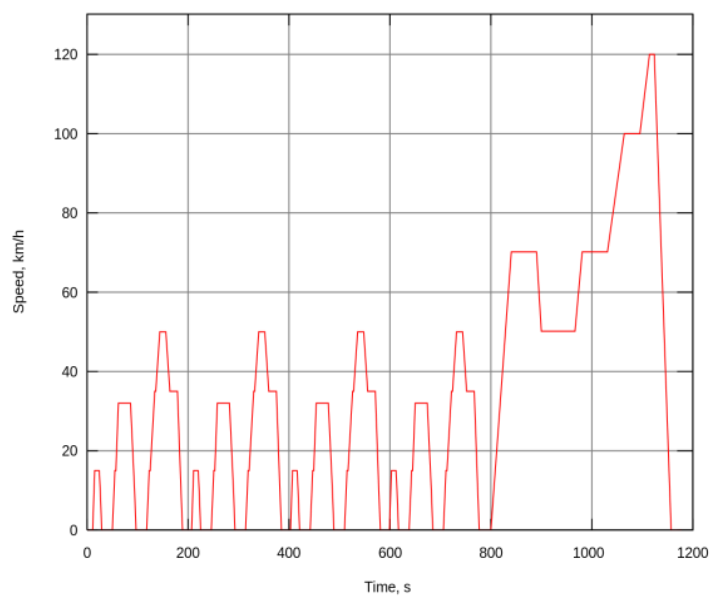

Gambar 1.

Siklus Urban dan Extra Urban pada Standar uji UN ECE R101 
b. Metode Perhitungan

Perhitungan emisi diperoleh dari pengukuran konsentrasi emisi yang ditangkap dari sampling bag. Perhitungan konsumsi bahan bakar dilakukan dengan metode carbon balance dari emisi gas buang kendaraan. Emisi gas buang yang dibutuhkan dalam perhitungan adalah:

- Karbon monoksida (CO)

- Total hidrokarbon (HC)

- Karbon dioksida $\left(\mathrm{CO}_{2}\right)$

Adapun formula yang digunakan untuk proses perhitungan emisi adalah ${ }^{10)}$ :

$$
M_{i}=\left(\frac{V o l_{m i x} \times \rho_{i} \times C_{i} \times 10^{-6}}{D}\right)
$$

Dimana :

$$
\begin{array}{ll}
\mathrm{Mi} & : \text { Jumlah emis }(\mathrm{gr} / \mathrm{km}) \\
\text { Volmix } & \begin{array}{l}
\text { Volume exhaust dilusi gas } \\
\text { (liter) }
\end{array} \\
\mathrm{\rho} & \begin{array}{l}
\text { : Densitas dari polutan } \\
\text { (gr/liter) }
\end{array} \\
\mathrm{Ci} & \begin{array}{l}
\text { : Konsentrasi dari polutan } \\
\text { (ppm) } \\
\text { : Jarak tempuh selama } \\
\text { pengujian }(\mathrm{km})
\end{array} \\
\mathrm{D} &
\end{array}
$$

Perhitungan konsumsi bahan bakar dihitung dalam satuan per $100 \mathrm{~km}$. Berikut ini adalah persamaan yang digunakan untuk perhitungan konsumsi bahan bakar ${ }^{10)}$ :

Kendaraan bermesin Otto - bensin :

$$
F C=\left(\frac{0.1154}{D}\right)\left[(0.866 \times H C)+(0.429 \times C O)+\left(0.273 \times C_{2}\right)\right]
$$

Kendaraan bermesin Otto - CNG :

$$
F C_{\text {norm }}=\left(\frac{0.1336}{0.654}\right)\left[(0.749 \times H C)+(0.429 \times C O)+\left(0.273 \times C O_{2}\right)\right]
$$

Keterangan:
FC : Fuel consumption dalam liter per $100 \mathrm{~km}$ (untuk bensin dan diesel) atau $\mathrm{m}^{3}$ per $100 \mathrm{~km}$ untuk CNG
$\mathrm{HC}$ : Emisi hidrokarbon dalam $(\mathrm{g} / \mathrm{km})$
$\mathrm{CO}$ : Emisi karbon monoksida dalam $(\mathrm{g} / \mathrm{km})$
$\mathrm{CO}_{2}$ : Emisi karbon dioksida dalam $(\mathrm{g} / \mathrm{km})$
D : Densitas bahan bakar uji $\left(\mathrm{gram} / \mathrm{cm}^{3}\right)$

\section{Perangkat Pengujian}

Pengujian dilakukan dengan menggunakan perangkat peralatan sebagai berikut:

a. Chassis dynamometer AVL

Chassis dynamometer adalah sebuah peralatan berupa rollerl silinder yang bisa berputar bebas sebagai tempat/ landasan berputarnya roda-roda penggerak kendaraan bermotor ketika diuji. Alat ini dilengkapi dengan sensor beban dan sensor-sensor lainnnya (temperatur, tekanan udara, kelembaban, putaran, dII) yang terhubung ke komputer monitor dan kendali. Roller juga terhubung dengan sebuah rem/ beban magnetik yang dapat dikontrol melalui komputer kendali, sehingga dapat mensimulasikan beban. Karakteristik utama dari chassis dynamometer adalah harus mampu mensimulasi beban jalan (dalam hal ini mencakup juga simulasi inersia) sebagai fungsi kecepatan kendaraan, sehingga ketika kendaraan diuji berjalan di atas chassis dynamometer tersebut kondisinya mendekati kondisi nyata di jalan raya.

b. Constant volume sampling AVL CVS i60

Sistem pengambilan sampel gas buang dirancang untuk memudahkan pengukuran massa emisi gas buang kendaraan dalam keadaan sebenarnya. Sistem yang digunakan adalah sistem Constant Volume Sampler (CVS). Pada sistem ini dilakukan pengenceran gas buang kendaraan secara terus menerus dengan jalan mencampur dengan udara bebas yang kondisinya terkontrol. Untuk CVS diesel terdapat tambahan berupa sistem penukar kalor.

c. Gas analyser AVL AMA i60

Gas analyser digunakan untuk menganalisa kandungan sampel gas buang yang telah terdilusi dengan peralatan CVS. Gas analyser ini terdiri atas peralatan:

i. Analisis karbon monoksida (CO) dan karbon dioksida $\left(\mathrm{CO}_{2}\right)$ harus dari jenis absorpsi non-dispersive Infra Red (NIDR)

ii. Analisis hidrokarbon (HC) kendaraan bensin harus dari jenis Flame Ionization Detector (FID) 
iii. Analisis hidrokarbon - kendaraan diesel harus dari jenis Flame Ionization Detector (FID) dan dengan pemanasan aliran $190+10^{\circ} \mathrm{C}$.

\section{Kendaraan dan Bahan Bakar Uji}

a. Kendaraan Uji

Pengujian konsumsi bahan bakar (fuel economy) telah dilakukan pada mobil sebagai berikut:

i. Kendaraan sedan bifuel bensinCNG 1 (1500 cc)

ii. Kendaraan MPV bifuel bensingas 2 (1500 cc)

Spesifikasi teknis kendaraan uji adalah sebagai berikut:

1. Kendaraan sedan bifuel bensin-CNG, spesifikasi engine-nya ditunjukkan pada tabel dibawah :

Tabel 1.

Spesifikasi Engine Kendaraan Sedan Bifuel Bensin-CNG

\begin{tabular}{|c|c|c|c|c|}
\hline & & & CNG & Gasoline \\
\hline \multirow{7}{*}{ Engine } & Type & & \multicolumn{2}{|c|}{ SOHC VTEC } \\
\hline & Jumlah silinder & & \multicolumn{2}{|c|}{4 silinder segaris } \\
\hline & Displacement & $\mathrm{cc}$ & \multicolumn{2}{|c|}{1.497} \\
\hline & Bore $x$ stroke & $\mathrm{mm}$ & \multicolumn{2}{|c|}{$73,0 \times 89,4$} \\
\hline & $\begin{array}{c}\text { Compression } \\
\text { ratio }\end{array}$ & - & \multicolumn{2}{|c|}{10,4} \\
\hline & Daya maksimum & $\begin{array}{c}\mathrm{kW} \\
(\mathrm{PS}) / \mathrm{rpm}\end{array}$ & $77(102) / 6600$ & $88(120) / 1600$ \\
\hline & Torsi maksimum & $\mathrm{Nm} / \mathrm{rpm}$ & $128 / 4800$ & $146 / 4800$ \\
\hline
\end{tabular}

2. Kendaraan MPV bifuel bensin-gas, spesifikasi engine-nya ditunjukkan pada tabel dibawah :

Tabel 2

Spesifikasi Engine Kendaraan MPV Bifuel Bensin-Gas

\begin{tabular}{|c|c|c|c|}
\hline \multirow{5}{*}{ Engine } & Type & & $\begin{array}{c}\text { 3SZ-VE DOHC VVT-i } \\
\text { berpendingin air }\end{array}$ \\
\cline { 2 - 4 } & Jumlah silinder & & 4 silinder segaris \\
\cline { 2 - 4 } & Displacement & $\mathrm{cc}$ & 1495 \\
\cline { 2 - 4 } & Bore $x$ stroke & $\mathrm{mm}$ & $72,0 \times 91,8$ \\
\cline { 2 - 4 } & $\begin{array}{c}\text { Compression } \\
\text { ratio }\end{array}$ & - & \\
\cline { 2 - 4 } & Daya maksimum & $\mathrm{PS} / \mathrm{rpm}$ & $97 / 6000$ \\
\cline { 2 - 4 } & Torsi maksimum & $\mathrm{Nm} / \mathrm{rpm}$ & $134 / 4400$ \\
\hline & Bahan bakar & & Bensin tanpa timbal \\
\hline
\end{tabular}

b. Bahan Bakar Uji

Bahan bakar yang digunakan dalam pengujian tersebut berbagai jenis bensin dan CNG adalah:

i. Compressed Natural Gas (CNG)

ii. Bensin $88 \# 1$

iii. Bensin 92 \#2

iv. Bensin $92 \# 3$

v. Bensin 95 \#4
Pengulangan dalam pengujian rata-rata dilakukan sebanyak tiga kali untuk tiap bahan bakar uji, untuk menghasilkan data yang lebih valid dan representatif.

\section{HASIL DAN PEMBAHASAN}

\section{Konsumsi Bahan Bakar}

Hasil perbandingan pada pengujian konsumsi bahan bakar untuk berbagai pemakaian bahan bakar pada berbagai kendaraan uji, yaitu dengan engine berbahan bakar bensin dan gas CNG ditunjukkan Gambar 2 di bawah :

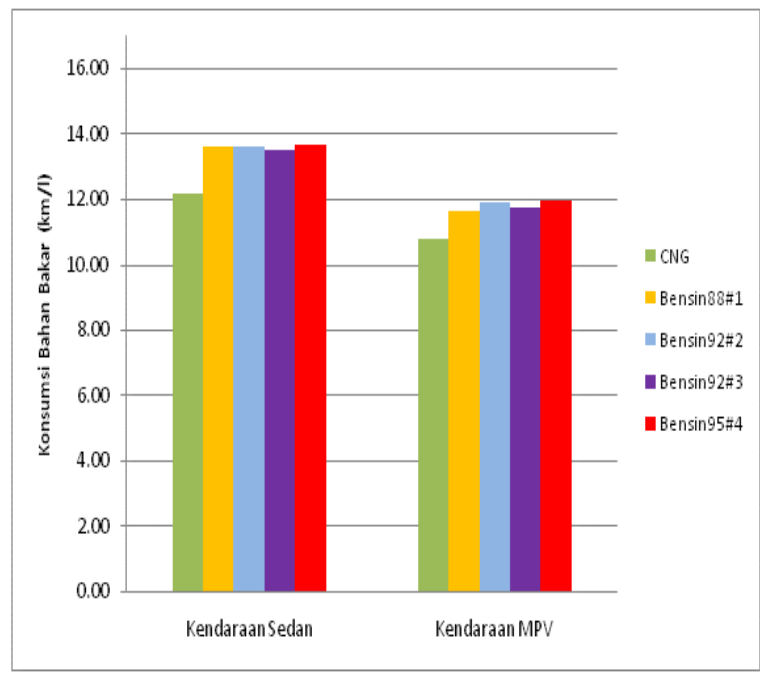

Gambar 2.

Grafik Perbandingan Hasil Uji Konsumsi

Bahan Bakar Kendaraan Bensin dan Gas untuk 2 Jenis Kendaraan

Untuk konsumsi bahan bakar dalam satuan $\mathrm{km}$ per liter, jenis bahan bakar bensin pada masing-masing kendaraan uji secara umum menggambarkan perbedaan terutama untuk pemakaian bahan bakar dengan nilai oktan yang lebih tinggi akan memberikan dampak terhadap hasil konsumsi bahan bakar yang lebih irit. Hal ini dapat dipertimbangkan karena hasil pembakaran yang lebih sempurna dengan kandungan oktan yang lebih tinggi. Hasil pengujian menunjukkan bahwa pemakaian bahan bakar jenis bensin yang mempunyai nilai oktan 95 memberikan hasil yang lebih hemat dibandingkan bahan bakar lainnya.

Selanjutnya, Gambar 2 menunjukkan pemakain bahan bakar gas jenis CNG pada 2 jenis kendaraan uji bermesin bensin-gas (Bifue). Dari gambar tersebut terlihat bahwa pemakaian bahan bakar gas memberikan nilai konsumsi bahan bakar dalam $\mathrm{km}$ per liter 
setara premium (LSP) yang lebih rendah dari pada rata-rata pemakaian bahan bakar jenis bensin, dengan selisih 10,09\% untuk kendaraan jenis sedan dan 8,9\% untuk kendaraan jenis MPV. Sehingga bisa disimpulkan pemakaian bahan bakar gas lebih boros dibanding pemakaian bahan bakar jenis bensin pada kedua kendaraan Bifuel tersebut. Pada penelitian ini, nilai satu liter setara premium yang digunakan dalam perhitungan setara dengan 0,954 $\mathrm{m}^{3} \mathrm{CNG}$. Nilai tersebut diperoleh dari artikel yang dikeluarkan oleh Lemigas-ESDM ${ }^{11}$. Walaupun mempunyai nilai oktan yang cukup tinggi tapi nilai konsumsi bahan bakar yang bahan bakar CNG lebih rendah dibandingkan bahan bakar cair lainnya yang disebabkan karena nilai densitas CNG yang jauh lebih rendah dibandingkan semua jenis bahan bakar jenis cair lainya.

Untuk hasil konsumsi bahan bakar jika dibandingkan antara kedua kendaraan bermesin bensin-CNG (Bifuel) yang yang digunakan, kendaraan bermesin bensin-gas sedan terlihat lebih hemat dibandingkan dengan kendaraan bermesin bensin-gas MPV, rata-rata sekitar $14,8 \%$. Hal ini dikarenakan teknologi engine serta optimasi pembakaran yang diterapkan pada kedua kendaraan tersebut.

\section{Emisi Kendaraan}

\section{a. Emisi Karbon Dioksida $\left(\mathrm{CO}_{2}\right)$}

Perbandingan kandungan $\mathrm{CO}_{2}$ dalam emisi gas buang untuk berbagai jenis bahan bakar dan kendaraan ditampilkan pada Gambar 3.

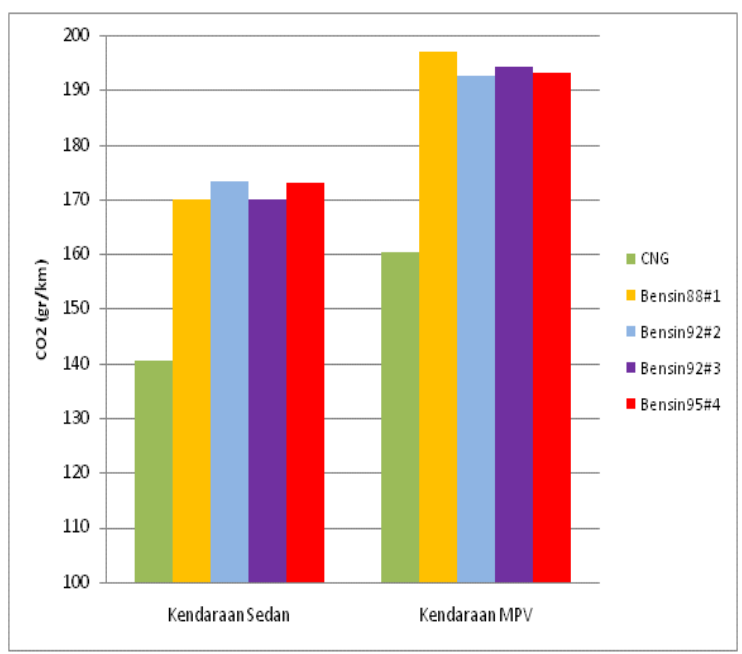

Gambar 3.

Grafik Perbandingan Emisi $\mathrm{CO}_{2}$ dari Variasi Bahan Bakar dan Kendaraan Uji
Gambar 3 menunjukkan emisi $\mathrm{CO}_{2}$ pada penggunaan bahan bakar CNG menunjukkan nilai yang relatif lebih rendah dibandingkan bahan bakar jenis bensin pada kedua kendaraan Bifuel tersebut. Hal ini berkaitan dengan rasio $\mathrm{H} / \mathrm{C}$ CNG (4:1) yang lebih tinggi dari bensin $(1,85: 1)$. Untuk bahan bakar jenis cair, perbedaan RON akan berakibat pada emisi $\mathrm{CO}_{2}$ yang dihasilkan walaupun dalam selisih yang relatif kecil jika dibandingkan dengan perbedaan antara CNG dan bahan bakar cair. Gambar 3 tersebut juga menunjukkan bahwa teknologi kendaraan berpengaruh terhadap emisi $\mathrm{CO}_{2}$ yang dihasilkan, dalam hal ini kendaraan sedan menghasilkan emisi $\mathrm{CO}_{2}$ yang lebih rendah dibandingkan dengan kendaraan MPV ratarata sekitar $11,82 \%$ dari semua jenis bahan bakar.

\section{b. Emisi Karbon Monoksida (CO)}

Perbandingan nilai emisi karbon monoksida dari berbagai jenis bahan bakar dan kendaraan ditampilkan ditunjukkan dalam Gambar 4.

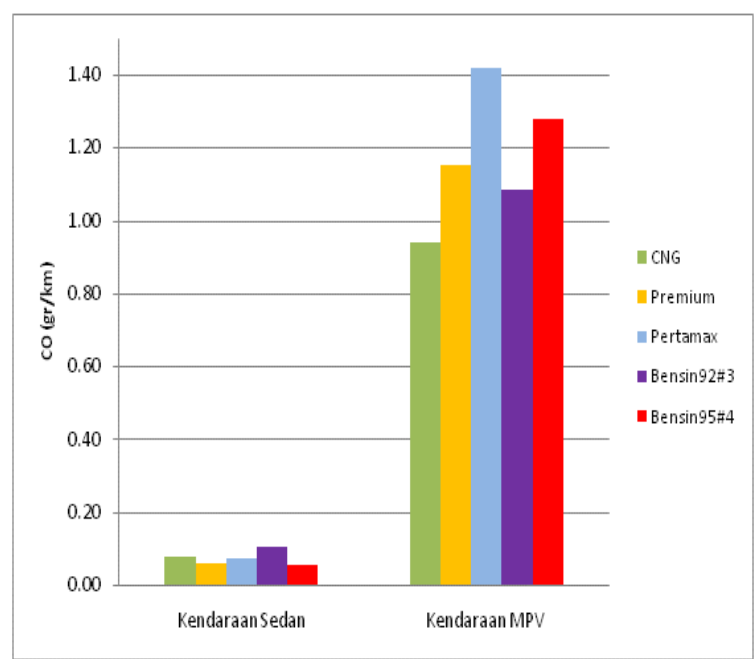

Gambar 4

Grafik Perbandingan Emisi CO dari Variasi Bahan Bakar dan Kendaraan Uji

Gambar 4 menunjukkan bahwa pemakaian bahan bakar bensin dengan kandungan oktan yang lebih tinggi akan menghasilkan emisi CO yang lebih rendah daripada pemakaian bahan bakar dengan nilai oktan yang rendah. Untuk kendaraan MPV, bahan bakar gas menunjukkan hasil yang lebih rendah dibandingkan dengan bahan bakar bensin yang digunakan tetapi untuk sedan perbedaan semua bahan bakar relatif kecil. Hal ini dapat dijelaskan karena untuk kendaraan sedan telah menggunakan 
catalytic converter sehingga perbaikan pembakaran oleh bahan bakar gas relatif tidak terlihat. Tetapi untuk kendaraan MPV terlihat bahwa perbaikan pembakaran CNG dapat menunjukkan pengaruh yang cukup signifikan dalam menurunkan emisi gas buang karbon monoksida. Gambar 4 tersebut juga menunjukkan bahwa teknologi kendaraan sedan lebih baik dari kendaraan MPV dalam mengoptimasi pembakarannya sehingga emisi $\mathrm{CO}$ yang dikeluarkan jauh lebih kecil, sekitar $93,48 \%$ dari rata-rata bahan bakar yang digunakan.

\section{c. Emisi Hidrokarbon (HC)}

Perbandingan nilai emisi hidrokarbon dari kendaraan dengan berbagai bahan bakar dan kendaraan ditunjukkan dalam Gambar 5.

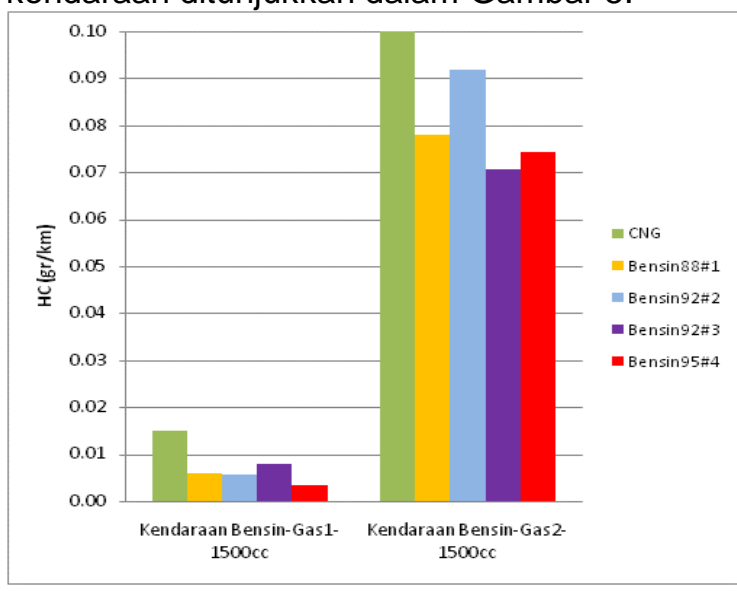

Gambar 5.

Grafik Perbandingan Emisi HC dari Variasi Bahan Bakar dan Kendaraan Uji

Gambar 5 menunjukkan bahwa kendaran sedan dengan teknologi pembakaran dan after treatment emisi gas buang yang lebih sempurna dapat mengurangi emisi $\mathrm{HC}$ yang cukup rendah dibandingkan kendaraan MPV, dengan perbedaan sekitar $92,89 \%$ dari ratarata bahan bakar yang digunakan. Gambar 5 juga menunjukkan bahwa pemakaian bahan bakar gas CNG ternyata menghasilkan nilai emisi $\mathrm{HC}$ yang relatif cukup tinggi dibanding penggunaan bahan bakar minyak jenis bensin, baik untuk kendaraan sedan maupun MPV. Hal yang sesuai dengan hasil penelitian lain ${ }^{5,7)}$ ini diduga diakibatkan karena rasio bahan bakar udara yang tidak optimum sehingga dapat menyebabkan kemungkinan pendinginan dinding silinder ruang bakar lebih cepat yang dapat mengganggu proses pelepasan panas sehingga menyisakan bahan bakar yang tidak terbakar.

\section{d. Emisi NOx}

Perbandingan nilai emisi NOx dari kendaraan dengan berbagai bahan bakar dan kendaraan ditunjukkan dalam Gambar 6 .

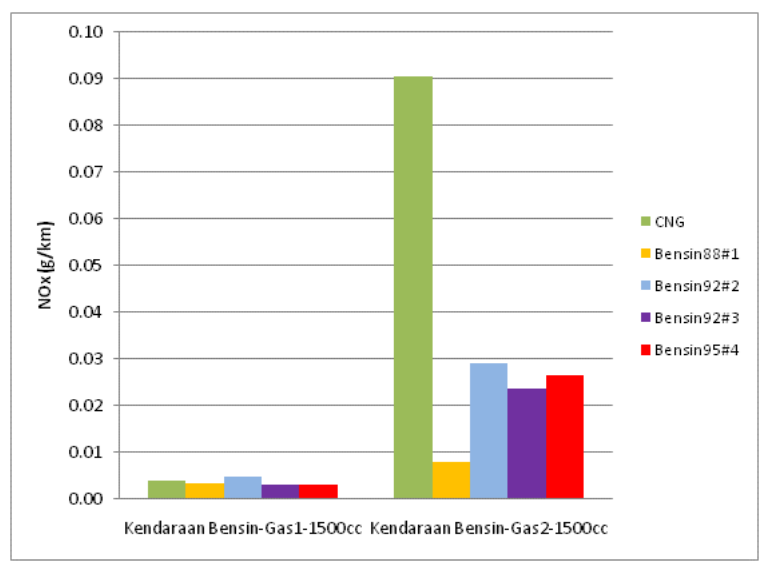

Gambar 6.

Grafik Perbandingan Emisi NOx dari Variasi Bahan Bakar dan Kendaraan Uji

Dari Gambar 6 tersebut terlihat bahwa pemakaian bahan bakar gas CNG ternyata menghasilkan nilai emisi NOx yang relatif lebih tinggi dibanding penggunaan bahan bakar minyak jenis bensin untuk kendaraan MPV, sedangkan adanya catalytic converter pada sedan mampu menekan emisi NOx pada level yang sangat rendah terlepas dari jenis bahan bakar yang digunakan, dimana perbedaan nilai emisi NOx untuk pemakaian gas CNG dari kedua kendaraan tersebut mencapai 95,6\%. Hal ini diduga diakibatkan karena perbaikan pembakaran terutama pada daerah beban menengah dan atas sehingga temperatur pembakaran menjadi tinggi. Hal ini menyebabkan pembentukan NOx yang didominasi pada daerah pembakaran temperatur tinggi menjadi besar.

\section{Biaya Operasional Bahan Bakar}

Perhitungan juga dilakukan untuk biaya pemakaian bahan bakar yang dikeluarkan untuk kendaraan uji tersebut. Gambar 7 menunjukkan biaya bahan bakar yang digunakan kendaraan uji per kilometer. Perhitungan untuk meninjau fuel economy dari sisi biaya pemakaian bahan bakar dengan acuan harga bahan bakar per Maret 2018 berdasarkan harga satuan per liter untuk bahan bakar bensin atau per liter setara premium (LSP) untuk gas, yaitu :
- CNG
- Bensin $88 \# 1$
Rp 3.100
- Bensin 92 \#2
: Rp 6.550
- Bensin 92 \#3
Rp 8.900
- Bensin 95 \#4
Rp 9.350
Rp 10.100 
Hasil perhitungan dan perbandingan tersebut ditampilkan dalam grafik pada Gambar 7.

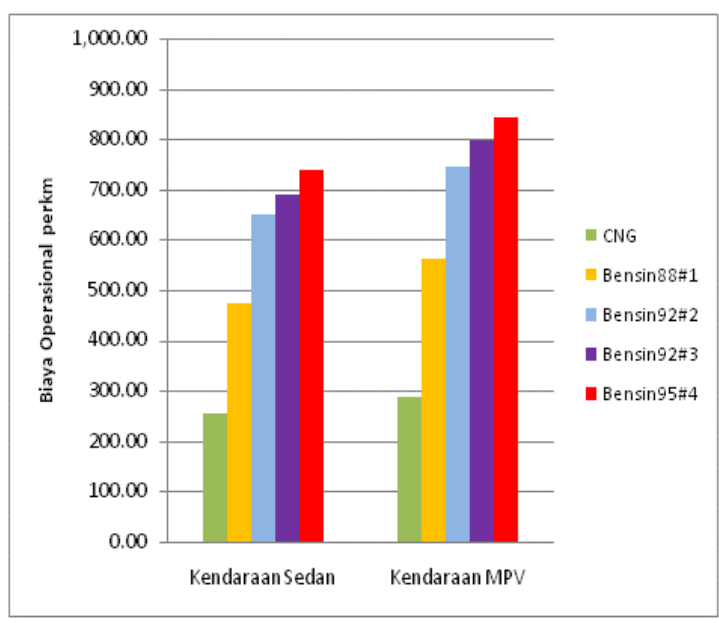

Gambar 7.

Grafik Perbandingan Biaya Operasional Bahan Bakar per km pada Berbagai Bahan Bakar dan Kendaraan

Untuk analisa tiap-tiap bahan bakar jenis bensin yang digunakan, bahan bakar bensin 88\#1 masih mempunyai nilai biaya yang paling rendah, karena harga per liternya yang paling murah, selanjutnya bensin 92\#2 dan bensin 92\#3. Sebaliknya pemakain bahan bakar bensin $95 \# 4$ menghasilkan nilai biaya yang paling tinggi, hal tersebut juga masih dikarenakan harga per liternya yang paling mahal.

Selanjutnya apabila membandingkan jenis bahan bakar cair tersebut dengan CNG maka biaya operasional bahan bakar cukup murah terjadi pada pemakaian bahan bakar gas CNG. Hal ini bisa dilihat pada hasil pengukuran pada kedua kendaraan Bifuel yang digunakan. Terjadi perbedaan yang yang cukup signifikan antara biaya operasioanal penggunaan bahan bakar gas dan bahan bakar minyak jenis bensin yaitu pada kendaraan uji jenis sedan rata-rata $59,0 \%$ dan kendaraan uji jenis MPV rata-rata $60,0 \%$. Hal ini karena harga per-liter setara premium (LSP) untuk gas CNG masih jauh di bawah harga bahan bakar minyak khususnya jenis bensin. Potensi yang besar terkait keekonomisan dalam pemakaian CNG menurut kajian dari Jacqueline, et $a^{(9)}$ harus didukung dengan penyediaan infrastruktur untuk CNG secara merata. Selain hal itu, kebijakan nasional seperti insentif pajak yang sebetulnya sudah memiliki payung hukum yaitu PP No.33 Tahun 2013 juga sudah selayaknya diaplikasikan karena selain biaya keekonomisan yang menguntungkan untuk pengguna kendaraan juga pemakaian CNG dapat menekan emisi $\mathrm{CO}_{2}$ yang dihasilkan.
Hal ini dapat membantu pemerintah Indonesia dalam komitmennya menurunkan emisi $\mathrm{CO}_{2}$ tahun 2025 sebesar $25 \%$.

\section{SIMPULAN}

Kesimpulan yang dapat diambil dari kajian fuel economy ini adalah Untuk variasi pemakaian bahan bakar bensin pada kendaraan yang sama, yaitu dihasilkan pemakaian bahan bakar dengan nilai oktan yang tinggi sedikit akan menghasilkan penghematan pemakaian bahan bakar dalam $\mathrm{km} / \mathrm{liter}$, seiring dengan rendahnya nilai emisi $\mathrm{CO}$ dan $\mathrm{CO}_{2}$. Diperoleh perbedaan nilai pemakaian bahan bakar tersebut untuk kendaraan uji jenis sedan dengan catalytic converter sebesar $0,06 \mathrm{~km} / \mathrm{liter}$ atau $0,5 \%$ dan kendaraan uji jenis MPV mencapai 0,34 $\mathrm{km} / \mathrm{liter}$ atau $2,9 \%$. Sehingga dari pengujian yang dilakukan penggunaan bensin 95\#4 sedikit lebih irit dibanding bensin lain yang nilai oktannya lebih rendah, seperti pada bensin 88\#1.

Jika dilihat dari nilai ekonomis untuk kedua jenis kendaraan tersebut yaitu berapa biaya yang dikeluarkan tiap satuan liter $(\mathrm{Rp} / \mathrm{km})$, harga bahan bakar masih sangat mempengaruhi hasil. Harga paling mahal untuk per liter ada pada bahan bakar bensin $95 \# 4$, oleh karena itu biaya pemakaiannya juga paling mahal. Sebaliknya harga CNG paling murah per liter setara premium (LSP), sehingga biaya pemakaian bahan bakar tesebut masih paling murah walaupun secara konsumsi pemakaiannya dalam $\mathrm{km} /$ liter paling boros. Perbedaan nilai ekonomis pemakaian CNG yang dihasilkan dibandingkan dengan pemakaian berbagai bahan bakar bensin yang digunakan pada kajian ini dalam satuan $\mathrm{Rp} / \mathrm{km}$ pada kendaraan uji jenis sedan adalah dari $46,4 \% \sim 65,5 \%$. Sedangkan pada kendaraan uji jenis MPV mempunyai nilai ekonomis sekitar 48,9\% 65,8\%.

\section{UCAPAN TERIMAKASIH}

Pada kajian ini kami mengucapkan terimakasih kepada kepala BT2MP-BPPT yang telah mendukung dilakukannya kajian ini dan rekan rekan tim pengujian di Laboratorium Emisi Kendaraan Bermotor yaitu Ibu Siti Yubaidah,M.T selaku Ka. Lab. pada waktu itu yang memfasilitasi kajian ini, serta penanggung jawab kegiatan Bapak Taufik Yuwono, ST,yang melakukan koordinasi dan perhitungan serta tim uji Bapak M. Agus Wijayanto,ST dan Bapak Jumadi yang telah melakukan pengujian sehingga kajian ini dapat selesai sesuai dengan rencana. 


\section{DAFTAR PUSTAKA}

1. Ira, F., et al, Outlook Energi Indonesia 2017, PTSEIK-BPPT: Jakarta, 2017.

2. Kementerian Sekretariat Negara RI, Peraturan Pemerintah No. 41 Tahun 1999 tentang Pengendalian pencemaran udara, 1999.

3. Kementerian Lingkungan Hidup RI, Peraturan Menteri Lingkungan Hidup No. 141 Tahun 2009 tentang Ambang batas emisi gas buang tipe baru dan Tahun 2003 tentang Ambang batas emisi gas buang tipe baru dan kendaraan bermotor yang sedang diproduksi.

4. Zhiliang, Y., et.al., On road emission characteristics of CNG fueled bifuel taxis, Atmospheric Environment 94 (2014) 198204, 2014.

5. Yanuandri. P., et.al., Evaluation of performance and emission of SI engine fueled with CNG at low and high load condition, Energy Procedia 68 (2015):147156, 2015.
6. Hayder, A.A., dan K.A. Ahmad, HCNG fueled Sparklgnition (SI) engine with its effects on performance and emissions, Renewable and Sustainable Energy Review 82 (2018): 324-342, 2018.

7. Riesta, A., et.al., Performance and emission characteristics of DME mixed LGV as alternative fuel for SI engine, Energy Procedia 65 (2015) 274-281, 2015.

8. Muhamad A., dan Diachirta C.A.D.T., Analyze experiment for Vigas and Pertamax to performance and Exhaust Emission for Gasoline Motor 2000 cc, Journal of Physics: Conf. Series 962 (2018) 012024, 2018.

9. Jacqueline L.K., et.al., Exploring th market for compressed natural gas (CNG) light commercial vehicle in the United Kingdom, Transportation Research Part D 29 (2014): 22-31, 2014.

10. The United Nations Economic Commission for Europe (UNECE), UN ECE R101 standard, 2005.

11. http://www.lemigas.esdm.go.id/id/prdkpen elitian-269-htm, diakses Bulan Februari Tahun 2015 
(halaman ini sengaja dikosongkan) 